\title{
Water Use for Shale Gas Extraction in the Sichuan Basin, China
}

\author{
Jianliang Wang ${ }^{1}$, MingmingLiu ${ }^{2}$, Yongmei Bentley ${ }^{3}$, Lianyong Feng ${ }^{1}$, Chunhua Zhang $^{4}$ \\ 1 China University of Petroleum (Beijing), School of Business Administration, 102249,
} 18 Fuxue Road, Changping District, Beijing, China. Email: fenglyenergy@163.com (Feng L.Y.)

2 China University of Petroleum (Beijing), Academy of Chinese Energy Strategy, 102249, 18 Fuxue Road, Changping District, Beijing, China. Email:

liumingming18@163.com (Liu M.M.)

3 University of Bedfordshire, Luton LU1 3JU, UK. Email:

Yongmei.Bentley@beds.ac.uk (Bentley Y.)

4 Economics \& Technology Research Institute, CNPC, Beijing, China. Email: zhangch003@cnpc.com.cn

Corresponding author: Jianliang Wang (wangjianliang305@163.com).

\begin{abstract}
:
This study investigates the use of water for extracting shale gas in the Sichuan Basin of China. Both net water use and water intensity (i.e., water use per unit of gas produced) of shale wells are estimated by applying a process-based life cycle inventory (LCI) model. The results show that the net water use and water intensity are around 24500 $\mathrm{m}^{3} /$ well and $1.9 \mathrm{~m}^{3}$ water $/ 10^{4} \mathrm{~m}^{3}$ gas respectively, and that the fracturing and completion stage of shale gas extraction accounts for the largest share in net water use. A comparison shows that China's water use for shale gas extraction is generally higher than that of other countries. By considering the predicted annual drilling activities in the Sichuan Basin, we find that the annual water demand for shale gas development is likely to be negligible compared to total regional water supply. However, considering the water demand for shale gas extraction and the water demand from other sectors may make water availability a significant concern for China's shale gas development in the
\end{abstract}


future.

Keywords: Shale gas; China; Life cycle inventory; Water use; Water intensity; Estimated ultimate recovery 


\section{Introduction}

Climate change resulting from the use of fossil fuel has become a critical issue which threatens the sustainable development of human society. An important way to deal with this issue is to promote the transition of the global energy system from high-carbon energy resources to low-carbon energy resources. Natural gas, a relatively clean energy source compared to coal and oil, has been recently characterized as a 'bridge fuel' for the world to achieve this transition process (Vidic et al., 2013). In this respect, the International Energy Agency (IEA) forecasts that the world may enter a 'golden age' of natural gas (IEA, 2011), in which case expanding the supply of natural gas has become a crucial task for the world.

Shale gas is natural gas that is found trapped within shale formations. Due to the vast resource base of shale gas and its wide distribution (EIA, 2013), shale gas development could play an important role in expanding the world supply of natural gas. Horizontal drilling and hydraulic fracturing have significantly reduced the barriers to shale gas development, and made the extraction of shale gas economically feasible (Vidic et al., 2013). However, these technologies are not free from environmental risks. In particular, the literature has pointed out that these two techniques are significantly water consuming, and large-scale development of shale gas resources can present a very large demand on local water resources (Jiang et al., 2014; Clark et al., 2013; Wan et al., 2014). Moreover, like climate change, the lack of water resources is potentially a significant threat for human society (Rijsberman, 2006). Humans should not wish to solve one problem by creating another, and hence it is necessary for the world to understand the impacts of shale gas development on water resources, and then deal with these impacts.

A number of studies have analyzed the water use of shale gas development. The various studies can be divided into three categories: The first category analyzes qualitatively the impacts of shale gas development on water use, such as Wan et al. (2014), Vengosh et al. (2014) and Guo et al. (2017); and where the contribution of such studies is to raise the public's overall awareness of environmental risks of shale gas development. The second category of studies estimates quantitatively the amount of 
water use of shale gas development, or the total demand on regional water resources, such as Dale et al. (2013), Clark et al. (2013), Chang et al.(2014a), Jiang et al. (2014) and Chen and Carter (2016); and where the contribution of these studies is to measure the environmental risks for industrial operators or policy makers. The third category is research into the potential ways to reduce the amount of water use by strengthening water resources management or developing advanced technologies; these studies include Rahm et al. (2013), Zhang et al. (2016) and Onishi et al. (2017).

Of all these studies, the scientific assessment of environmental impacts (i.e. the second category of studies) is the most important, since it provides the base for controlling or reducing risks. A review of this second category of studies shows that their results differ significantly. For example, Nicot and Scanlon (2012) conclude that the average water use per well for shale gas development is less than $11000 \mathrm{~m}^{3}$, while this number in Clark et al. (2013) is more than $23000 \mathrm{~m}^{3}$. A number of reasons could be responsible for these differences, the most important of which is likely to be the differences in geological conditions of different shale basins, because the well depth and the amount of fracturing fluids required are related to the geological conditions (Chang et al., 2014a; Wang and Feng, 2016). Therefore, one of the key ways to improve the world's understanding of the environmental impacts of shale gas development is to expand the geographical areas of study.

Most current studies have focused on the U.S., mainly because of its relatively mature shale gas industry and the large amount of data accumulated (Jiang et al., 2014; Clark et al., 2013; Stephen et al., 2014). However, as potentially the world's largest resource of shale gas (EIA, 2013), China has made ambitious development plans for its shale gas resources, and a number of international institutes forecast that China will be the largest developer of shale gas outside the U.S. (BP, 2016). Therefore, analyzing the environmental impacts of China's shale gas development will help in the public understanding of the worldwide environmental impacts of shale gas development.

In 2014, based on the limited data from China's first horizontal well-W201H1 in the Sichuan Basin, Chang et al. (2014a) carried out the first quantitative study of water use per well for China's shale gas development. However, as noted in Chang et al. 
(2014a), W201H1 was a test well, rather than a production well. Therefore, in terms of data, the study carried out by Chang et al. (2014a) should be seen as a preliminary study, and to achieve a proper understanding of the impact of shale gas development on water use, more specific data should be used as they become available. Following Chang et al. (2014a) a number of studies appeared which analyzed the overall water demand on local water resources by considering the amount of water use per well and the development plans for shale gas in a specific region; such as Chang et al. (2014b), Yu et al. (2016) and Guo et al. (2016). However, the key data inputs to these studies are originally from Chang et al. (2014a) or from a combination of U.S. and China sources.

Thus the main aim of this paper is to give a relatively comprehensive assessment of water use for shale gas production in China by using more specific data for Chinese shale wells, and reflecting production behavior in practice, and by then analyzing the overall water demand on local water resources based on these comprehensive results.

\section{Methods}

This paper focuses on not only the water use, but also the water intensity of the shale gas production (defined as net water use per well divided by the estimated ultimate recovery (EUR) of the well). Besides, Sichuan basin is chosen as the target area since it is one of the main prospective areas for shale gas exploration and development in China, and also most current activities of shale gas development are concentrated in this basin (Dong et al., 2014).

To evaluate the water use of shale gas development, a process-based life cycle inventory (P-LCI) model is developed. This section is organized as follows: 1) Definition of the system boundary; 2) Description of the life cycle of shale gas development; 3) Introduction of the estimation approach for EUR; and 4) Introduction of the estimation procedures.

\subsection{System Boundary}

The system boundary includes four stages, i.e. site preparation, drilling, fracturing and completion, and production, while other stages, such as distribution, storage and use stages are not considered. The attributable processes or activities for each stage are also defined (Figure 1), and are described in detail in the following parts of this section. Two 
metric functions are applied in this paper, one is cubic meter water use per well $\left(\mathrm{m}^{3}\right.$ water/well) to reflect the net water use; the other is the water intensity, given by cubic meters of water use per ten thousand cubic meter of gas production $\left(\mathrm{m}^{3}\right.$ water $/ 10^{4} \mathrm{~m}^{3}$ gas).

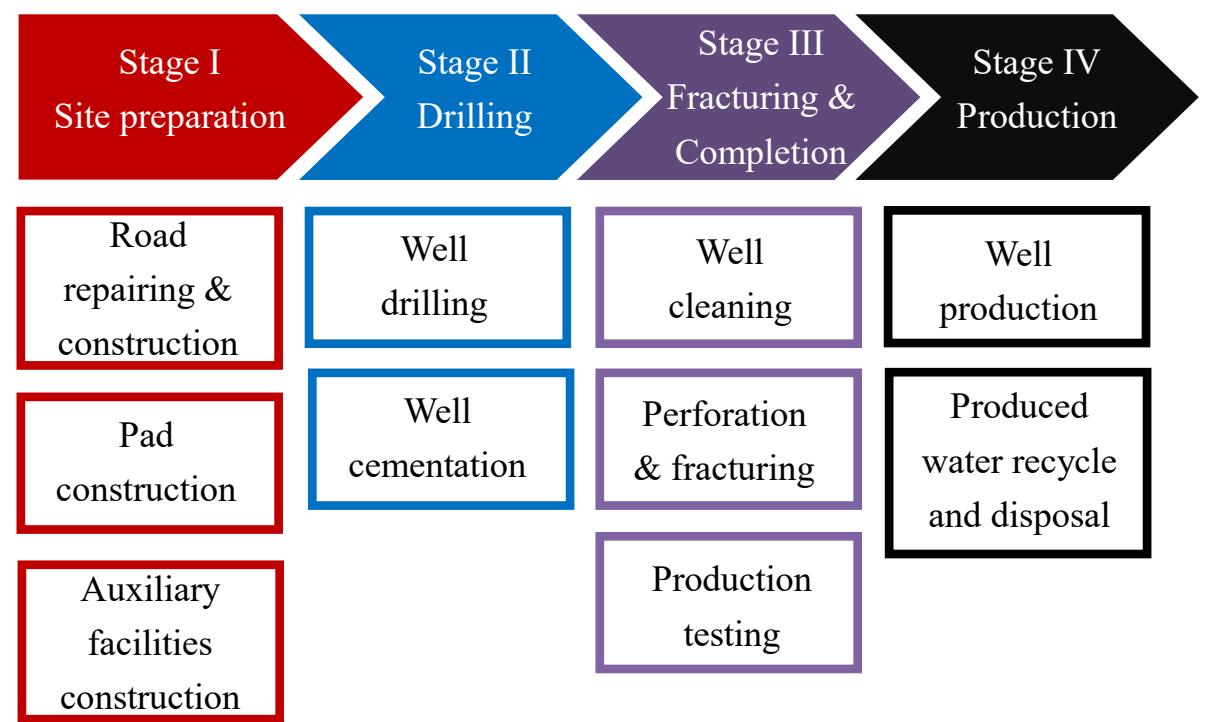

Figure 1. Stages and attributable activities of shale gas development

\subsection{Description of the shale gas life cycle}

\subsubsection{Site preparation stage}

The site preparation stage usually includes three attributable activities, i.e. road repairing and construction, pad construction and auxiliary facilities construction. This paper only considers the water use in auxiliary facilities construction, since there is no significant water use in road repairing and construction and pad construction (Chang et al., 2014a). Auxiliary facilities mainly include a wastewater sink, freshwater impoundment, solidification and landfill, flare pit and some living facilities, such as temporary rooms for workers' cooking and living, toilets and garbage pits (PetroChinaSOC, 2014a, 2014b, 2014c). The construction of these living facilities is not considered in this paper due to little water use in their construction.

The wastewater sink is mainly used for treatment and storage of produced waste liquids during drilling and fracturing stages. The size of a wastewater sink ranges from $1200 \mathrm{~m}^{3}$ to $3200 \mathrm{~m}^{3}$ (average value: $2200 \mathrm{~m}^{3}$ ), where detailed data sources can be seen 
in Table S1 in the Supplementary Information (SI). The concrete is prepared on site and used to prevent the percolation of the wastewater sink (PetroChina-SOC, 2014a, 2014b, 2014c). Therefore, the water use in the construction of the wastewater sink is the water used for concrete preparation. The detailed water use estimate is given in SI.

Freshwater impoundment is mainly used for storage of freshwater that is transported from off-site and mainly used for drilling and fracturing. The size of a typical freshwater impoundment ranges from $2800 \mathrm{~m}^{3}$ to $10000 \mathrm{~m}^{3}$ (average value: $7500 \mathrm{~m}^{3}$; see Table S1 in SI). Different from the wastewater sink, the freshwater impoundment uses a waterproof fabric instead of concrete to prevent percolation, since its main function is to temporarily store the freshwater and freshwater has little impact on environment. Therefore, there is no water use in freshwater impoundment construction.

Solidification and landfill is mainly used for treatment of the solid waste produced during the stages of drilling and fracturing, such as drill cuttings. The size of the solidification and landfill facility ranges from $2400 \mathrm{~m}^{3}$ to $5000 \mathrm{~m}^{3}$ (average value: 3400 $\mathrm{m}^{3}$; see Table S1 in SI). A flare pit is mainly used for flaring gas during the period of production testing after fracturing (NDRC, 2004). The size of the flare pit ranges from $50 \mathrm{~m}^{3}$ to $400 \mathrm{~m}^{3}$ (average value: $200 \mathrm{~m}^{3}$; see Table S1 in SI). Similar to the wastewater sink, the concrete is used to prevent the percolation for both the solidification and landfill facility, and the flare pit. The estimated water use in the construction of these two facilities is given in SI.

In addition to the activities discussed above, workers' living activities also need water (i.e. on-site living water use). The water use for on-site living is estimated based on water use per person per day and the total days needed in this stage, and the detailed calculation is also included in SI.

It should be noted the water use estimated in this stage is for one pad rather than for one well, since for shale gas, one pad usually has six wells in the Sichuan basin to reduce extraction cost per well (this mode is called "well-factory"). To present a more practical analysis this paper estimates the average water use per well by dividing the volume of the water use for one pad by the number of wells (see Table S2 in SI). 


\subsubsection{Drilling stage}

The drilling stage includes two processes or activities, i.e. well drilling and well cementation. A well will be firstly drilled in a vertical direction until a "kick-off point" (KOP) is reached, where the orientation of the drill bit will be changed. Then, this nonlinear drilling directs the well into the desired geological formation, at which point drilling continues in a horizontal direction until the designed length of the well. In addition, a well is usually reinforced with multiple layers of steel casing and cement during its drilling process. A typical shale gas well in the Sichuan basin usually has four casing strings: conductor, surface casing, intermediate casing, and production casing (see Figure 2).

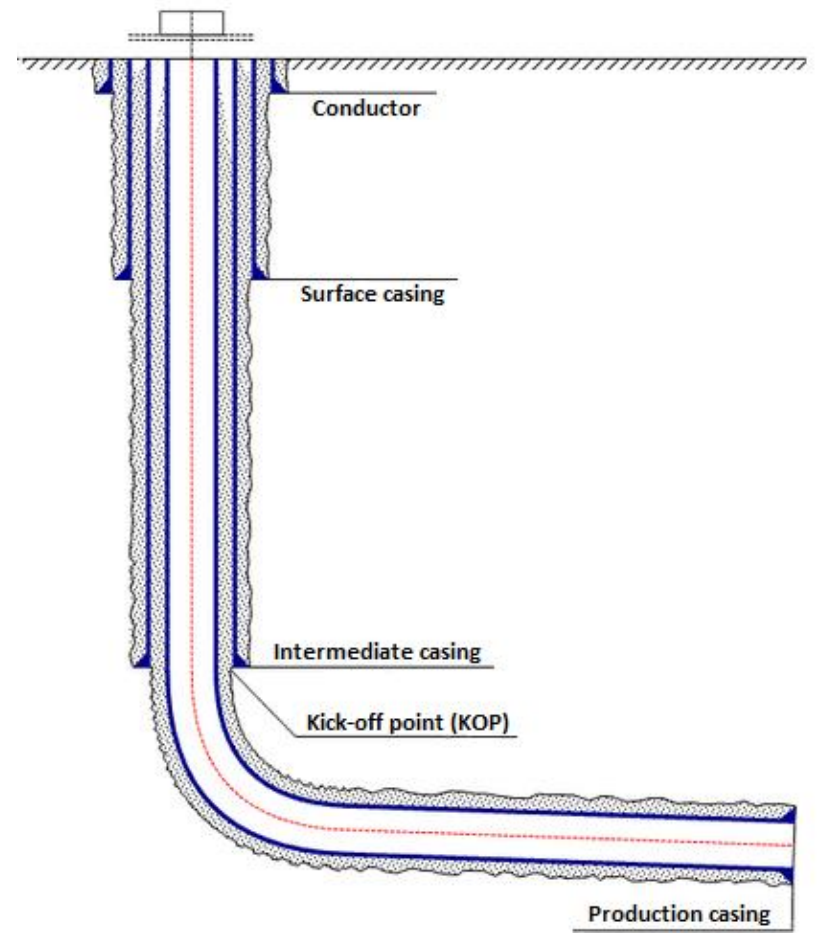

Figure 2. A typical design of a shale-gas well

In the well drilling process, drilling muds are necessary to control the formation pressures, maintain wellbore stability, keep the drill bit cool and clean during drilling, and carrying out drill cuttings etc. Two types of drilling muds are usually used in the Sichuan basin: 1) a water-based drilling mud, which is used before the drill bit enters the desired geological formation, and 2) an oil-based drilling mud, which is used after the drill bit has entered the desired geological formation to improve the security and 
stability of the wellbore (Tang et al., 2011). The volume of water could account for 70$85 \%$ of total volume of water-based muds in Sichuan (Nan, 2017; Peng et al., 2017). For oil-based muds, in Sichuan, the percentage of oil may range from 50\%-70\% (He et al., 2012; Cheng et al., 2014; Wu et al., 2014). The water use in this process is the water used for preparing the drilling fluid, and is estimated to be 1049-3047 $\mathrm{m}^{3}$ (average value: $2100 \mathrm{~m}^{3}$ ); where detailed estimates can be found in SI. Furthermore, the waste drilling water from one well is usually partially recycled and reused for other wells within the same pad (PetroChina-SOC, 2015a, b). Therefore, the actual net freshwater use per well will be lower than $2100 \mathrm{~m}^{3}$ if this kind of waste drilling water recycle mode is applied. This paper considers this recycle mode, since it has already been widely used in the Sichuan basin to save water resources. A detailed description of the recycle mode, and estimate of the average net freshwater use per well in drilling process, are given in SI.

In the well cementation process, the water use is the water used for preparing the cement slurry (cement slurry is used to cement the rocks and casings), and its volume is significantly influenced by two key factors, i.e. the length of different casing strings and the weight of cement slurry. The analyses of these key factors and estimates of the water use are described in SI.

In addition to the activities discussed above, on-site living water use for this stage is also estimated by using the same method mentioned in previous section, and its results are shown in detail in SI.

\subsubsection{Fracturing and completion stage}

Based on the practice of shale gas development in the Sichuan basin, the fracturing and completion stage usually includes well cleaning, well perforation and fracturing, and production testing. Freshwater is usually used in well cleaning and estimated to be 105 $\mathrm{m}^{3}$ per well (PetroChina-SOC, 2015a, 2015b).

Well perforation uses perforating guns to penetrate the production casing, cement and the desired formation to create tunnels that act as conduits through which reservoir fluids flow from the formation, into the wellbore and up to the surface. Unlike conventional gas, a fracturing treatment is typically needed for a shale formation due 
to its very low permeability. Once the shale formation is fractured, proppants (sand is a common proppant) will be injected to keep the induced cracks open. In China, hydraulic fracturing is currently the most widely used fracturing technique due to its low cost and lower formation damage (Huang et al., 2012).

For the consumed fracturing fluid, some vertical wells which are drilled in the very early development period in the Sichuan basin used only several thousand cubic meters of fracturing fluid (Nie et al., 2013), while some wells used also nearer $50000 \mathrm{~m}^{3}$ of fracturing fluid (Tang et al.,2011); however, both these two cases are not common. Most current horizontal wells in the Sichuan basin typically consume between 10253-40237 $\mathrm{m}^{3}$ (average value: $26071 \mathrm{~m}^{3}$ ) of fracturing fluid (see Table S6 in SI). The water use is assumed to be the same volume as the consumed fracturing fluid, due to its dominant share.

A portion of the injected fracturing fluid will return to the surface during production testing in the fracturing and completion stage (these fluids are called flowback water and are produced from the well immediately after hydraulic fracturing and before commencing gas production). Another portion of the fluid will be produced along with the shale gas over the lifespan of the well in the production stage (these fluids are called produced water). The remainder of the injected fracturing fluid will stay in the formation.

The flowback rate is usually low due to the short period of production testing. According to Liu et al. (2015), in China it ranges typically between $2 \%$ and $12 \%$, with an average value of $5.4 \%$. To reduce the water use, about $85 \%$ of flowback water is recycled and reused for other wells within the same pad. The rest is transported to the Qifu wastewater treatment plant or disposed of via deep well injection (PetroChinaSOC, 2014a, 2014b, 2014c, 2014d; CNPC-CDEC, 2014). Due to the recycling the actual freshwater usage per well is lower than the amount of injected water. Recycling of flowback water is considered in this paper; the detailed calculation of the net freshwater per well is shown in SI.

In addition to the activities discussed above, on-site living water use during this stage is also considered and estimated by using the same approach mentioned 
previously. The estimated results can be found in SI.

\subsubsection{Production stage}

The production stage mainly includes gas production and produced water recycling and disposal. There is no freshwater input during this stage. The produced water during this stage is mainly from two sources: one is the original injected fracturing water; the other is formation water. However, there are no complete statistics to show how much produced water will finally return to the surface, since the production period in the Sichuan basin is still short. According to Jiang et al. (2014), $1 \times 10^{6} \mathrm{~m}^{3}$ of gas production will generate $15 \mathrm{~m}^{3}$ water. Thus we can estimate the volume of produced water by multiplying $15 \mathrm{~m}^{3}$ water per $1 \times 10^{6} \mathrm{~m}^{3}$ gas production by the EUR estimated in section 2.3. The recycle volume of produced water can be then estimated by multiplying the produced water by its recycle rate (see SI).

\subsection{EUR estimate for China's shale gas wells}

The EUR estimate for a given well is crucial for the water intensity calculation. Three important parameters are widely used to describe shale well performance, and to estimate the EUR. These are: the initial production (IP), production decline rate and the well lifetime (Stephen et al., 2014; Lanrenzi et al., 2013; Yu et al., 2016).

Based on our investigation, the test gas production rate (where, generally, the initial production is lower than the test production rate) during fracturing and completion stage can be very high; for example, the test production of Yuanba\#21 well was $50.7 \times 10^{4}$ $\mathrm{m}^{3} / \mathrm{d}$ (Dong et al., 2014). However, this is only a rare case. Most wells have a much lower test production rate. For example, based on the 53 wells with their test production data from various sources (including: Liu et al., 2015; Dong et al., 2014; Ren et al., 2015; Yin et al., 2014; He, 2014; Xu and Zhang, 2015; Yang et al., 2014; Zou et al., 2013; Guo et al., 2014; Fang et al., 2015; Zhang and Zhu, 2014; Yang et al., 2015), we estimate that the typical test production rate of $96 \%$ of wells is less than $30 \times 10^{4} \mathrm{~m}^{3} / \mathrm{d}$ (average production: $9.4 \times 10^{4} \mathrm{~m}^{3} / \mathrm{d}$ ); of $85 \%$ of wells' production is lower than $20 \times 10^{4}$ $\mathrm{m}^{3} / \mathrm{d}$ (average production: $6.7 \times 10^{4} \mathrm{~m}^{3} / \mathrm{d}$ ); and of $57 \%$ of wells' production is lower than $10 \times 10^{4} \mathrm{~m}^{3} / \mathrm{d}$ (average production: $3.7 \times 10^{4} \mathrm{~m}^{3} / \mathrm{d}$ ). Therefore, the initial production rate 
of shale gas is assumed to be $3 \times 10^{4} \mathrm{~m}^{3} / \mathrm{d}$ for the low case, $9 \times 10^{4} \mathrm{~m}^{3} / \mathrm{d}$ for the high case, and $6 \times 10^{4} \mathrm{~m}^{3} / \mathrm{d}$ for the average case. The average case is consistent with the initial production values given in Chang et al. (2015), Yuan et al. (2015) and Xia et al. (2015).

Liu et al. (2014) first analyzed the production decline rate of China's shale wells in the Sichuan basin and proposed a unique production decline curve (see Table 1). This production decline curve has also been applied in other literature, such as $\mathrm{Yu}$ et al. (2016). Our paper also uses Liu et al.'s proposed production decline curve to estimate the shale wells' EUR in the Sichuan basin. The well lifetime is estimated to be $20-30$ years (average value: 25 years) (Yu et al., 2016; Yuan et al., 2015; Liu et al., 2014; Wang et al., 2014).

Table 1. Production decline rate of shale gas wells in the Sichuan basin

\begin{tabular}{|c|c|c|c|c|c|c|c|c|}
\hline Years & $\begin{array}{l}1 \mathrm{st} \\
\text { year }\end{array}$ & $\begin{array}{l}\text { 2nd } \\
\text { year }\end{array}$ & $\begin{array}{l}\text { 3rd } \\
\text { year }\end{array}$ & $\begin{array}{l}\text { 4th } \\
\text { year }\end{array}$ & $\begin{array}{l}\text { 5th } \\
\text { year }\end{array}$ & $\begin{array}{l}\text { 6th } \\
\text { year }\end{array}$ & $\begin{array}{l}\text { 7th } \\
\text { year }\end{array}$ & $\begin{array}{l}\geq 8 \text { th } \\
\text { year }\end{array}$ \\
\hline Decline rate & $40 \%$ & $33 \%$ & $20 \%$ & $10 \%$ & $8 \%$ & $7 \%$ & $6 \%$ & $5 \%$ \\
\hline
\end{tabular}

Data source: Liu et al. (2014)

Based on above assumptions, the EUR of shale gas wells in the Sichuan basin is estimated to be typically from $60.4-211.0 \times 10^{6} \mathrm{~m}^{3}$, with an average value of $132.0 \times 10^{6}$ $\mathrm{m}^{3}$.

\subsection{Estimation procedures of the developed model}

The procedure of our developed P-LCI model is shown as follows:

- Step 1 is to obtain the original inventory data from various sources. Data quality is a key factor influencing the validation of the estimated results. To improve the reliability and quality of the data, the data used in this paper are collected from four sources: 1) the operators' formal reports approved by the Chinese government, 2) the national standards released by the government, 3) peer-reviewed literature, and 4) interviews with operators (detailed data and their sources can be found in SI).

- Step 2 is to determine the parameters. Parameters are the model's inputs which affect the assessment results directly. Values for some parameters can be extracted 
from the data sources directly, while values for other parameters need to be estimated by using some methods and the data from data sources (detailed information for a number of methods can be seen in SI).

- Step 3 is to develop the P-LCI model. Two main models are developed: one is to estimate the total net water use per well, $\mathrm{W}_{t}$, see eq. (1); the other is to estimate the water intensity per well, $\mathrm{W}_{\text {Int. }}$, see eq. (2).

$$
\begin{gathered}
\mathrm{W}_{t}=\sum_{i=1}^{4} \mathrm{~W}_{i}=\sum_{i=1}^{4} f\left(x_{i, 1}, x_{i, 2}, \ldots, x_{i, n}\right) \\
\mathrm{W}_{\text {Int. }}=\mathrm{W}_{t} / E U R=\mathrm{W}_{t} / f(I P, D R, L T)
\end{gathered}
$$

where $\mathrm{W}_{i}$ is the water use for stage $i$ (the stages of shale gas production are shown in Figure 1); $x_{i, n}$ is the parameters which affecting the estimation of $\mathrm{W}_{i} ; E U R$ is the estimated ultimate recovery of the well; $I P$ is the initial production of the well; $D R$ is the production decline rate of the well; $L T$ is the lifetime of the well.

- $\quad$ Step 4 is to run the developed model. The values of the parameters from the Step 2 are used as the inputs for the models developed in Step 3. Finally, the output results are analyzed.

\section{Results and discussion}

\subsection{Water use and water intensity}

The total net water use per well in the Sichuan basin is estimated to be around 24500 $\mathrm{m}^{3} /$ well (range: $9700-37500 \mathrm{~m}^{3} /$ well), with detailed water use for each life cycle stage as shown in Figure 3. It should be noted the water use estimates in this section are all net water use, which means that the potential recycling and reuse of water resources for each life cycle stage have been considered. 


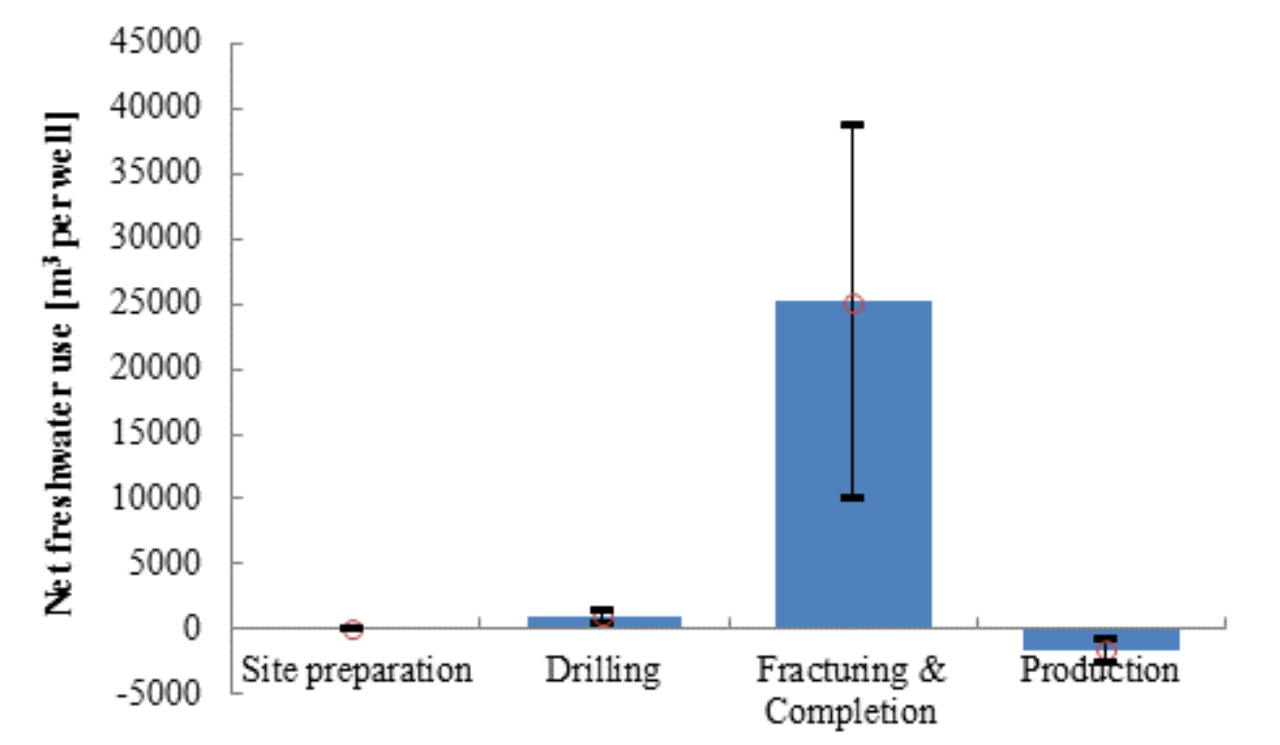

Figure 3. Estimated life cycle net water use for a shale well in the Sichuan basin

Note: Error bars represent the range of estimates

Based on our estimates, the highest net water use is from the fracturing and completion stage, which is estimated to be around $25200 \mathrm{~m}^{3} /$ well (average value), accounting for $103 \%$ of total net water use due to large amounts of injected fracturing water used in this stage and low flowback rate. The second highest water use is from the production stage. As mentioned in section 2.2.4, there is no water input in this stage, and in addition, parts of produced water can be recycled and reused in other wells in the same pad, which will help reduce the freshwater input for other wells. Therefore, the net water use in the production stage is negative and estimated to be around -1680 $\mathrm{m}^{3} /$ well (average value), accounting for $-7 \%$ of total net water use. The third highest water use is from the drilling stage. In the drilling stage, a Sichuan shale well usually needs to use $2100 \mathrm{~m}^{3}$ water as drilling fluid. However, the actual net water use may much lower than initial estimates due to the very low loss rate of drilling water under the ground and high recycle rate aboveground, as well as the applied "Well Factory" development mode. Based on our estimates, the net water use in the drilling stage is estimated to be around $940 \mathrm{~m}^{3} /$ well (average value), accounting for $3.8 \%$ of total net water use. The lowest water use is the water consumed in the site preparation stage, which is estimated to be only around $40 \mathrm{~m}^{3} /$ well (average value) due to the "Well Factory" development mode, accounting for $0.2 \%$ of total net water use. 
The water intensity can be then estimated to be around $1.9 \mathrm{~m}^{3}$ water $/ 10^{4} \mathrm{~m}^{3}$ gas by using the average values of EUR and total net water use per well. The situation of water intensity for each life cycle stage is similar with that in Figure 3, so the descriptions given in previous parts of this paper are omitted here to avoid replication.

\subsection{Sensitivity analysis}

Figure 4 shows the results of sensitivity analysis (only showing the six top parameters). We can see that the fracturing water use holds the greatest contribution to variance in total net water use; while both initial production of a shale gas well and fracturing water use have the greatest influences on variance in water intensity.
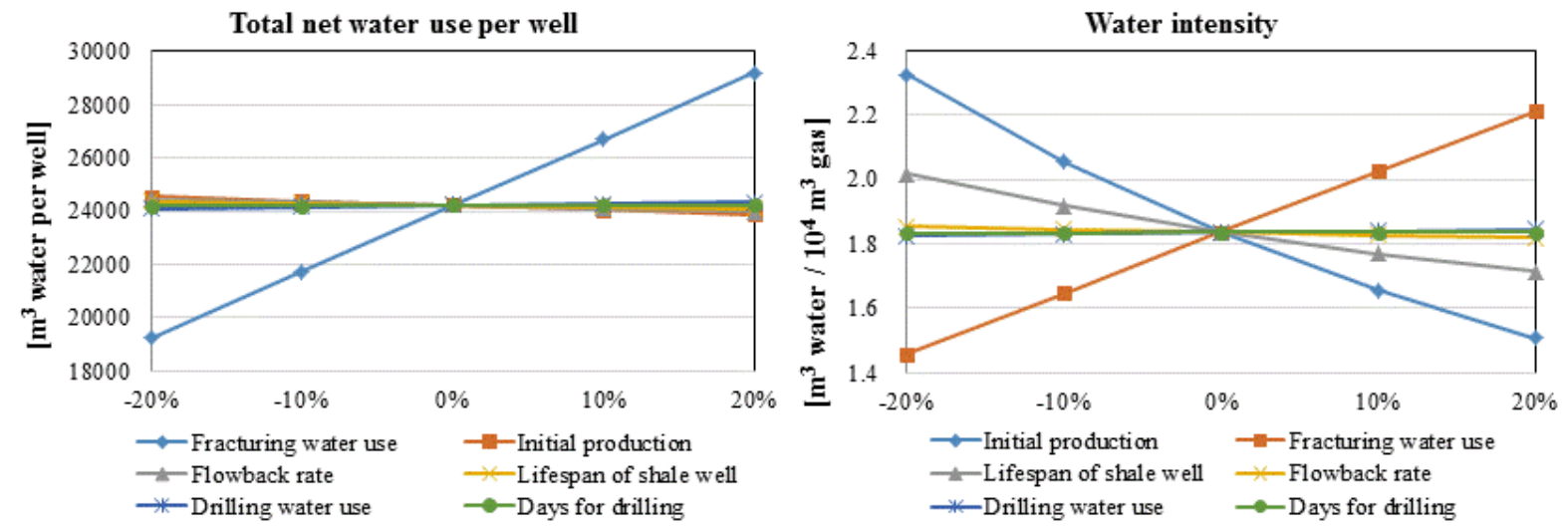

Figure 4. Sensitivity analysis of water use and water intensity to key model parameters or input variables

\subsection{Comparison the results of this paper with those of previous studies}

As mentioned previously, Chang et al. (2014a) presented the first quantitative analysis of shale gas development in China. Based on Chang et al. (2014a), the total water use per well was estimated to be around $25000 \mathrm{~m}^{3}$, which is consistent with this paper's average estimate, of $24500 \mathrm{~m}^{3}$ per well. However, the detailed estimation processes and parameters considered in each stage are significantly different (see Table 2).

Table 2. Comparison of the process and parameters in this paper and those of Chang et al. (2014a)

\begin{tabular}{|c|c|c|c|}
\hline \multirow{3}{*}{$\begin{array}{l}\text { Life cycle } \\
\text { stage }\end{array}$} & & Estimate from & \multirow{3}{*}{ Main reasons for the difference } \\
\hline & & Chang et al. (2014a) & \\
\hline & Range estimate $\left[\mathrm{m}^{3}\right]$ & Point estimate $\left[\mathrm{m}^{3}\right]$ & \\
\hline
\end{tabular}




\begin{tabular}{|c|c|c|c|}
\hline $\begin{array}{l}\text { Site } \\
\text { preparation }\end{array}$ & $\begin{array}{c}\quad 42 \\
\text { (range:30 61) }\end{array}$ & 85 & $\begin{array}{c}\text { This paper considers the production } \\
\text { behavior of "well factory" }\end{array}$ \\
\hline Drilling & $\begin{array}{c}940 \\
\text { (range:480 1346) }\end{array}$ & 1266 & $\begin{array}{l}\text { This paper considers the production } \\
\text { behavior of "drilling water recycling } \\
\text { and reuse" }\end{array}$ \\
\hline $\begin{array}{l}\text { Fracturing } \\
\& \\
\text { completion }\end{array}$ & $\begin{array}{c}25221 \\
\text { (range:9996 38861) }\end{array}$ & 23655 & $\begin{array}{l}\text { This paper considers well cleaning } \\
\text { and the production behavior of } \\
\text { "flowback water recycle and reuse " }\end{array}$ \\
\hline Production & $\begin{array}{c}\quad-1683 \\
\text { (range:-770 -2690) }\end{array}$ & & $\begin{array}{l}\text { This paper considers the production } \\
\text { behavior "produced water recycle" }\end{array}$ \\
\hline Total* & $\begin{array}{c}24500^{*} \\
\text { (range:9700 37500) }\end{array}$ & $25000 *$ & $\begin{array}{l}\text { This paper used more specific data } \\
\text { and different production behaviors }\end{array}$ \\
\hline
\end{tabular}

*May not sum directly to total due to rounding.

In the very early stage of China's shale gas industry, the main purpose of exploration and exploitation is to understand the shale formation, test the adaptability of techniques, and know the potential production capacity of shale gas wells. Therefore, in reality, the cost and environmental issues are generally ignored by operators. W201H1, which was used by Chang et al. (2014a) was a test well and was drilled in 2010 and finished in 2011, therefore, there was only one well in that pad and no recycle systems for water resources. In this case, the results of Chang et al. (2014a) reflect the basic situation under the early production behaviors. The well data used in this paper are for more recently drilled or produced wells, so the results in this paper reflect the current situation. From this perspective, both Chang et al.'s and this study are basically realistic descriptions for China's shale gas industry, and their difference can therefore be explained as the difference in production behaviors in different periods.

A comparison of average value in this paper and those in other literature is shown in Figure 5. For U.S. shales, we can see that Northeast Colorado shale region (11320 $\mathrm{m}^{3}$ water per well), Barnett shale region (10600-15031 $\mathrm{m}^{3}$ per well) and the Marcellus 
shale region (13036-15927 $\mathrm{m}^{3}$ per well) have comparatively lower values for net water use per well than the other three areas. The Haynesville shale region has the largest water use per well, with an estimated value of $21500-23044 \mathrm{~m}^{3}$ per well. Canada is the second largest country extracting its shale gas resources commercially after U.S. (Zhao et al., 2011). Alessi et al. (2017) and Goss et al. (2015) made a comprehensive comparative analysis of water use of four shale formations in North American, of which two are in Canada, i.e., Montney shale play (Located in Alberta [AB] and British Columbia $[\mathrm{BC}]$ ) and Duvernay shale play (Located in $\mathrm{AB}$ ). Based on the investigation of the data between November 2011 and March 2014 from the FracFocus database, Alessi et al. (2017) and Goss et al. (2015) show that the average water use for the hydraulically fractured wells in $\mathrm{AB}$ (mainly for Duvernay shale) and $\mathrm{BC}$ (mainly for Montney shale) are 3990 and $10430 \mathrm{~m}^{3}$ /well respectively. In 2014, Stamford and Azapagic (2014) carried out the first estimate of water use for U.K. shale gas development and showed that the water use is $13000 \mathrm{~m}^{3}$ per well in its middle case. Therefore, we can conclude that China typically has a larger water use per well in shale gas development compared to other regions shown in this paper.

A number of reasons could explain this phenomenon, but the most important reasons may be geology or formation conditions, the depth of burial of shale formations, and fracking techniques (Wang et al., 2014; Lee and Sohn, 2014; Zeng et al., 2013; Wang et al., 2017). First, the shale formations in China are more complex than those in the U.S. (Zhang et al., 2011); Second, the depths of most of the burial of shale formations in China are more than $3000 \mathrm{~m}$ which is higher than most of shale formations in the U.S. (Wang et al., 2012); Third, in practice, nearly all shale gas wells in China use slickwater fracturing, while some shale gas wells in U.S. and Canada may also use energized or energized slickwater fracturing (Alessi et al., 2017). It is known that slickwater fracturing technique consumes more water than energized or energized slickwater fracturing techniques (Alessi et al., 2017). All the reasons above may result in the higher water use in China's shale gas development. 


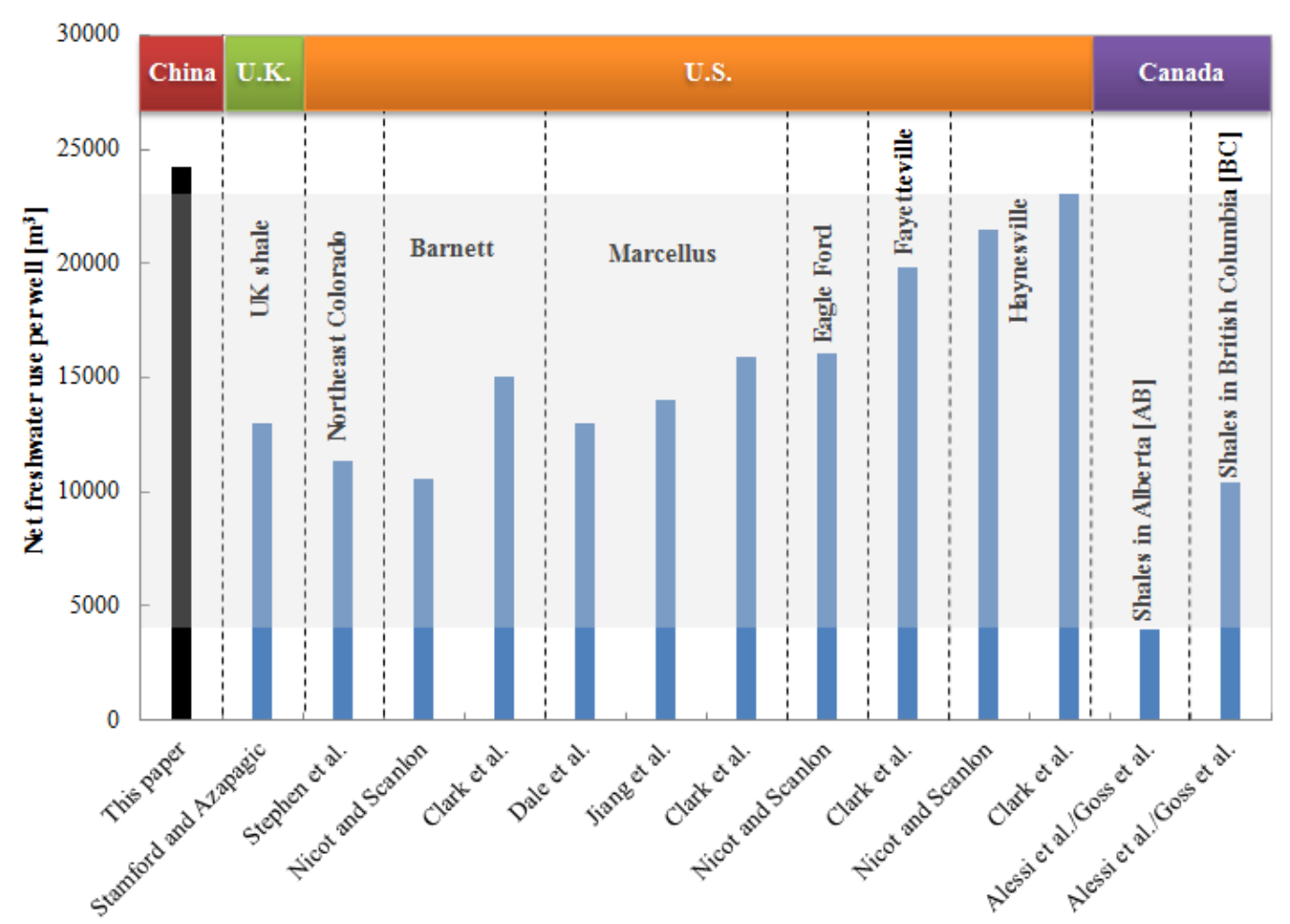

Figure 5. Comparison of the mean or median estimates of net water use per well of this and other studies

Data sources: Jiang et al. (2014); Clark et al. (2013); Stephen et al. (2014); Stamford and Azapagic (2014); Chang et al.(2014a); Nicot and Scanlon (2012); Dale et al. (2013); Alessi et al. (2017); Goss et al. (2015). The light band in this figure indicates the range of US, UK and Canada estimates

\subsection{Implications on regional water resources}

To promote its shale gas development, China has released its national shale gas development plan (NDRC, 2012), and sets out the aim of its shale gas production to reach more than 30 billion cubic meters (bcm) per year by 2020 (Yu et al., 2016). Furthermore, shale gas from the Sichuan basin is seen as the dominant contributor to this plan (Dong et al., 2014). Based on the drilling experience of the Haynesville shale region in the U.S., Yu et al. (2016) forecast the drilling rate (i.e. the number of wells drilled per year) for the Sichuan basin, and pointed out that the drilling rate will increase rapidly before 2021, and then reach its peak (about 1000 wells per year) and decline (Figure 6). Based on this forecast of drilling rate and our estimated water use per well, we can then estimate the future annual water demand of shale gas development in 
Sichuan basin (Figure 6). From Figure 6, we can see that the annual water demand will increase rapidly in the next few years and reach its peak in 2021, with a peak water demand of $24.5 \times 10^{6} \mathrm{~m}^{3}$ (range: $9.7-37.6 \times 10^{6} \mathrm{~m}^{3}$ ).

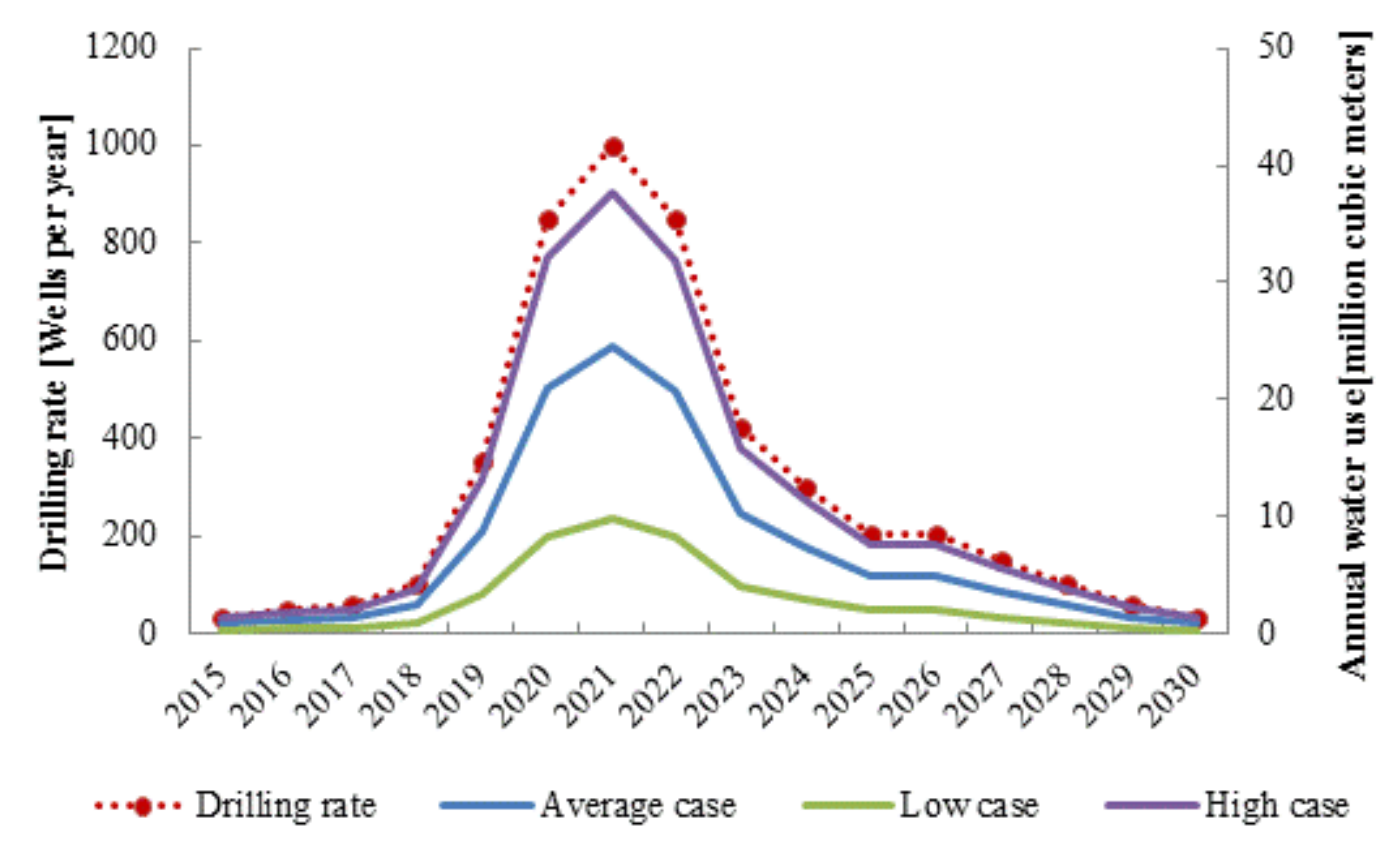

Figure 6. Projection of drilling rate and its related water use in Sichuan basin

Note: drilling rate is from Yu et al. (2016).

According to the latest water resources bulletins of Sichuan province and Chongqing municipality (the Sichuan shale basin mainly includes Sichuan province and Chongqing municipality), the total water supply in 2014 was about $23690 \times 10^{6} \mathrm{~m}^{3}$ for Sichuan province (SWRD, 2015) and $8050 \times 10^{6} \mathrm{~m}^{3}$ for Chongqing municipality (CWRB, 2015). Therefore, the predicted likely water demand for shale gas development can be seen as negligible relative to the total water supply. However, this does not mean the water use for shale gas development can be excluded in decision making, since there is likely to be a high competition between water demand from shale gas development and demand from other sectors. By considering the water demand and water availability in certain areas, Yu et al. (2016) established a water stress index to understand the potential competition between water use in shale gas development and water use in other sectors. They found, unfortunately, that the shale gas blocks in the Sichuan basin did indeed coincide with the areas with high to extremely high water 
stress.

\section{Conclusions}

The conclusions are summarized as follows:

First, the total net water use per shale gas well is estimated to be around 24500 $\mathrm{m}^{3} /$ well. By considering the breakdown of net water use, the fracturing and completion stage requires the largest share, while the site preparation stage has the smallest share. Furthermore, the water use in the production stage is negative. This is due to little water input, and the large water reuse from recycling of produced water.

Second, the water intensity per well (net water used per well lifetime $\mathrm{m}^{3}$ of gas produced) is also estimated, by considering the EUR of shale gas wells. Based on the analyses of initial production, decline rate and assumed lifespan of typical shale gas wells, the average EUR for a single shale well is around $132.0 \times 10^{6} \mathrm{~m}^{3}$. This then allows the net water intensity of shale gas production in the Sichuan basin in China to be estimated as $1.9 \mathrm{~m}^{3}$ water $/ 10^{4} \mathrm{~m}^{3}$ gas.

Third, a comparison of the average value of water use per well in this paper and those in other literature shows that China's shale gas development may consume more water than other countries. The main reason is likely to be the typically much greater depth of burial of the shale formation and the complex formation conditions, as well perhaps currently a lack of more advanced production techniques in China.

Finally, a forecast of total net water use for shale gas development in the Sichuan basin is conducted. The annual net water use for shale gas development in this basin is forecast to increase rapidly in the next few years, and reach a peak of $24.5 \times 10^{6} \mathrm{~m}^{3}$ in 2021 due to the peak of drilling rate. In comparing this quantity with current total water use in the same region, the impact of this water use on total regional water supply appears to be marginal. However, given the levels of local water stress already apparent in the region, the competition between water use in shale gas development and for other sectors could well be serious, and will need to be taken into account in decision-making.

\section{Acknowledgments}

This study has been supported by the National Natural Science Foundation of China 
(Grant Nos. 71503264 and 71673297), the Humanities and Social Sciences Youth Foundation of the Ministry of Education of China (Grant No. 15YJC630121) and the Major Program of the National Social Science Found of China (Grant No. 13 \& ZD159). We also received helpful comments from prof. Roger Bentley, an expert from Petroleum Analysis Centre, Ireland, and anonymous reviewers.

\section{References}

Alessi, D.S., Zolfaghari, A., Kletke, S., Gehman, J., Allen, D. M. et al., 2017. Comparative analysis of hydraulic fracturing wastewater practices in unconventional shale development: Water sourcing, treatment and disposal practices. Canadian Water Resources Journal, 42(2), 105-121. http://dx.doi.org/10.1080/07011784.2016.1238782, 2017.

BP, 2016. BP Energy Outlook, 2016 Edition. http://bp.com.cn/energyoutlook2016

Clark, C.E., Horner, R.M., Harto, C.B., 2013. Life cycle water consumption for shale gas and conventional natural gas. Environ. Sci. Technol. 47, 11829-11836. http://dx.doi.org/10.1021/es4013855

Chen, H.L., Wang, L., Zhou, F., Zhao, H., Zhang, H., 2014. Rapid and efficient drilling of horizontal wells in the Weiyuan shale gas field, Sichuan Basin. Natural Gas Industry, 34(12), 100-105. http://dx.chinadoi.cn/10.3787/j.issn.1000-0976.2014.12.014 (in Chinese)

Chen, H., Carter, K.E., 2016. Water usage for natural gas production through hydraulic fracturing in the United States from 2008 to 2014. J. Environ. Manage. 170, 152-159. http://doi.org/10.1016/j.jenvman.2016.01.023

Chang, Y., Huang, R., Ries, R.J., Masanet, E., 2014a. Shale-to-well energy use and air pollutant emissions of shale gas production in China. Appl. Energ. 14, 147-157. http://doi.org/10.1016/j.apenergy.2014.03.039

Chang, Y., Huang, R., Masanet, E., 2014b. The energy, water, and air pollution implications of tapping China's shale gas reserves. Resour. Conserv. Recy. 91, 100-108. http://doi.org/10.1016/j.resconrec.2014.07.015

Chang, Y., Huang, R., Ries, R.J., Masanet, E., 2015. Life-cycle comparison of greenhouse gas emissions and water consumption for coal and shale gas fired power generation in China. Energy 15, 335-343. http://doi.org/10.1016/j.energy.2015.04.034

CNPC Chuanqing Drilling Engineering Company Limited (CNPC-CDEC), 2014. Drilling Project Environmental Impact Assessment Report for W202H3, W204H5 and W204H6 Pads. TY(EIA)2014-036. December 2014.

Chongqing Water Resources Bureau (CWRB), 2015. Chongqing Water Resources Bulletin 2014. May 2015. http://www.cqwater.gov.cn/Pages/Home.aspx

Dong, D., Gao, S., Huang, J., Guan, Q., Wang, S., Wang, Y., 2014. A discussion on the shale gas exploration and development prospect in the Sichuan Basin. Nat. Gas Ind. 12, 1-15. http://dx.chinadoi.cn/10.3787/j.issn.1000-0976.2014.12.001 (in Chinese)

Dale, A.T., Vikas, K., Vidic, R.D., Bilec, M.M., 2013. Process based life-cycle assessment of natural gas from the Marcellus Shale. Environ. Sci. Technol. 10, 5459-5466. http://dx.doi.org/10.1021/es304414q 
Energy Information Administration of U.S. (EIA), 2013. Technically Recoverable Shale Oil and Shale Gas Resources: An Assessment of 137 Shale Formations in 41 Countries Outside the United States. June 2013. http://www.eia.gov/analysis/studies/worldshalegas/pdf/overview.pdf

Fang, D.Z., Zeng, H., Wang, N., Zhang, Y., 2015. Study on high production factors of high-pressure shale gas from Haynesville shale gas development data. Oil Drill. Product. Technol. 2, 58-62. http://dx.chinadoi.cn/10.13639/j.odpt.2015.02.016 (in Chinese)

Guo, J.C., Gou, B., Ren, S., Liu, L., Wang, X.W., 2014. Fracturing parameters optimization design for horizontal well with shale and sandstone inter beds in western Sichuan. Acta Petrol. Sin. 3, 511-518. http://dx.chinadoi.cn/10.7623/syxb201403013 (in Chinese)

Goss, G., Alessi, D., Allen, D., Gehman, J., Brisbois, J. et al., 2015. Unconventional Wastewater Management: A Comparative Review and Analysis of Hydraulic Fracturing Wastewater Management Practices Across Four North American Basins, Canadian Water Network.

Guo, M., Lu, X., Nielsen, C.P., McElroy, M.B., Shi, W., Chen, Y., Xu, Y., 2016. Prospects for shale gas production in China: Implications for water demand. Renew. Sust. Energ. Rev. 66, 742-750. http://doi.org/10.1016/j.rser.2016.08.026

Guo, M., Xu, Y., Chen, Y.D., 2017. Catching environmental noncompliance in shale gas development in China and the United States. Resour. Conserv. Recy. 121, 73-81. http://doi.org/10.1016/j.resconrec.2015.12.001

Huang, J.L., Zou, C.N., Li, J.Z., Dong, D.Z., Wang, S.J., Wang, S.Q., Wang, Y.M., Li, D.H., 2012. Shale gas accumulation conditions and favorable zones of Silurian Longmaxi Formation in south Sichuan Basin, China. J. China Coal Soc. 5, 782-787. http://www.mtxb.com.cn/EN/Y2012/V37/I05/782 (in Chinese)

He, T., Li, M.S., Yang, L.P., He, J., Zhao, S.J., Tan, B., Li, X.Y., 2012. Application of oil-based drilling fluid in shale gas horizontal well in district of Weiyuan. Drilling Fluid and Completion Fluid, 29(3), 1-5. http://dx.chinadoi.cn/10.3969/j.issn.1001-5620.2012.03.001 (in Chinese)

He, X.B., 2014. Optimization and Application of Production-Oriented Shale Gas Testing Technology in Fuling. J. Jianghan Petrol. U. Staff Work. 3, 30-33. http://d.wanfangdata.com.cn/Periodical/jhsyzgdxxb201403010 (in Chinese)

International Energy Agency (IEA), 2011. World Energy Outlook 2011 Special Report: Are We Entering a Golden Age of Gas?. 2011. http://www.iea.org/publications/freepublications/publication/WEO2011_GoldenAgeofGasReport.pd $\mathrm{f}$

Jiang, M., Hendrickson,C.T., Vanbriesen, J.M., 2014. Life cycle water consumption and wastewater generation impacts of a Marcellus shale gas well. Environ. Sci. Technol. 3, 1911-1920. http://dx.doi.org/10.1021/es4047654

Liu, Y.Q., Chen, P.F., Wu, W.G., Zhang, Q., Zhang, Y.D., Xie, B., Long, S.M., 2015. Technology research of the fracturing fluid for shale gas reservoir as "factory" fracturing: An example of the CNH3 well group "factory” fracturing. Chem. Eng. Oil Gas 4, 65-68. http://dx.chinadoi.cn/10.3969/j.issn.10073426.2015.04.014

Liu, J., Xu, H.T., Yu, G., Li, L., 2014. Development indices and potential of shale gas, Sichuan basin. Nat. Gas Explor. Dev. 2, 45-47. http://dx.chinadoi.cn/10.3969/j.issn.1673-3177.2014.02.011 (in Chinese)

Lee, W.J., Sohn, S.Y., 2014. Patent analysis to identify shale gas development in China and the United States. Energ. Policy 74, 111-115. http://doi.org/10.1016/j.enpol.2014.08.009 
Nicot, J.P., Scanlon, B.R., 2012. Water Use for Shale-Gas Production in Texas, U.S. Environ. Sci. Technol. 46, 3580-3586. http://dx.doi.org/10.1021/es204602t

Nie, J.S., Lei, Z.M., Wang, H.P., Wang, F.Y., 2013. Optimization of Casing Program for Shale Gas Horizontal Well in Weiyuan Structure. J. Chongqing U. Sci. Technol. 2, 97-100. http://dx.chinadoi.cn/10.3969/j.issn.1673-1980.2013.02.024

National Development and Reform Commission of China (NDRC), 2004. Well site preparation and layout requirements (SY/T5466-2004). Released on 3th July, 2004.

National Development and Reform Commission of China (NDRC), 2012. China's Five-year Shale Gas Development Plan. 2012-3-13. http://www.sdpc.gov.cn/zcfb/zcfbtz/201203/t20120316_467518.html

Nan, X., 2017. Research and application of different drilling fluid systems in shale gas horizontal wells in Southern of Sichuan. Thesis for Chemical Engineering at Northeast Petroleum University, China. April, 2017.

Onishi, V.C., Carrero-Parreño, A., Reyes-Labarta, J.A., Fraga, E.S., Caballero, J.A., 2017. Desalination of shale gas produced water: a rigorous design approach for zero-liquid discharge evaporation systems. J. Clean. Prod. 140, 1399-1414. http://doi.org/10.1016/j.jclepro.2016.10.012

PetroChina Southwest Oil \& Gas Filed Company (PetroChina-SOC), 2014a. Drilling Project Environmental Impact Assessment Report for W202H2 Pad.TY(EIA)-2014-021. May 2014.

PetroChina Southwest Oil \& Gas Filed Company (PetroChina-SOC), 2014b. Drilling Project Environmental Impact Assessment Report for W204H4 Pad.TY(EIA)-2014-014. June 2014.

PetroChina Southwest Oil \& Gas Filed Company (PetroChina-SOC), 2014c. Drilling Project Environmental Impact Assessment Report for W202H1 Pad, W204H1 Pad, and WH3-1 Well. March 2014.

PetroChina Southwest Oil \& Gas Filed Company (PetroChina-SOC), 2014d. Drilling Project Environmental Impact Assessment Report for W204H2 and W204H3 Pads.TY(EIA)-2014-015. June 2014.

PetroChina Southwest Oil \& Gas Filed Company (PetroChina-SOC), 2015a. Drilling Project Environmental Impact Assessment Report for W202H5 and W204H7 Pads. May 2015.

PetroChina Southwest Oil \& Gas Filed Company (PetroChina-SOC), 2015b. Drilling Project Environmental Impact Assessment Report for W202H4 and W202H6 Pads.TY(EIA)-2015-004. March 2015.

Peng, B., Zhou, F., Li, M.S., Zhang, J.L., 2017. Optimization and evaluation of anti-collapse water-based drilling fluids for shale gas horizontal wells:A case study of the Changning-Weiyuan National Shale Gas Demonstration Area. Natural Gas Industry, 37(3), 89-94. http://dx.chinadoi.cn/10.3787/j.issn.1000-0976.2017.03.012 (in Chinese)

Rijsberman, F.R., 2006. Water scarcity: Fact or fiction? Agr. Water Manage. 1, 5-22. http://doi.org/10.1016/j.agwat.2005.07.001

Rahm, B.G., Bates, J.T., Bertoia, L.R., Galford, A.E., Yoxtheimer, D.A., Riha, S.J., 2013. Wastewater management and Marcellus Shale gas development: Trends, drivers, and planning implications. J. Environ. Manage. 120, 105-113. https://doi.org/10.1016/j.jenvman.2013.02.029

Ren, Y., Qian, B., Zhang, J., Zhuo, Z.C., Qiao, L., 2015. Practice and understanding of industrial fracturing for shale gas of Longmaxi formation in Changning region. Oil Drill. Product. Technol. 4, 96-99. http://dx.chinadoi.cn/10.13639/j.odpt.2015.04.025

Stephen, G., Ken, C., Ken, K., Caleb, D., Luke, R., 2014. Water intensity assessment of shale gas resources in the Wattenberg field in northeastern Colorado. Environ. Sci. Technol. 10, 5991-5995. 
http://dx.doi.org/10.1021/es404675h

Stamford, L., Azapagic, A., 2014. Life cycle environmental impacts of UK shale gas. Appl. Energ. 134, 506-518. http://doi.org/10.1016/j.apenergy.2014.08.063

Sichuan Water Resources Department (SWRD), 2015. Sichuan Water Resources Bulletin 2014.12 October 2015. http://www.scwater.gov.cn/zyjhsq/11145.htm

Tang, Y., Tang, X., Wang, G.Y., Zhang, Q., 2011. Summary of hydraulic fracturing technology in shale gas development. Geol. Bull. China 2/3, 393-399. http://dx.chinadoi.cn/10.3969/j.issn.16712552.2011.02.026 (in Chinese)

Vidic, R.D., Brantley, S.L., Vandenbossche, J.M., Yoxtheimer, D., Abad, J.D., 2013. Impact of shale gas development on regional water quality. Science 6134. http://dx.doi.org/10.1126/science.1235009

Vengosh, A., Jackson, R.B., Warner, N., Darrah, T.H., Kondash, A., 2014. A critical review of the risks to water resources from unconventional shale gas development and hydraulic fracturing in the United States. Environ. Sci. Technol. 15, 8334-8348. http://dx.doi.org/10.1021/es405118y

Wan, Z., Huang, T., Craig, B., 2014. Barriers to the development of China's shale gas industry. J. Clean. Prod. 1, 818-823. http://doi.org/10.1016/j.jclepro.2014.04.073

Wang, L.S., Liao, S.M., Chen, G.S., Guo, G.A., Lu, Z.G., Fu, Y.Q., 2012. Bottlenecks and countermeasures in shale gas exploration and development of China. Natural Gas Industry, 31(2): 119-122. http://dx.chinadoi.cn/10.3787/j.issn.1000-0976.2011.12.021 (in Chinese)

Wu, B., Wang, J., Shu, F.C., Xiang, J.X., Nie, M.S., 2014. Study and Application of Oil-based Drilling Fluids for Horizontal Well Drilling. Journal of Oil \& Gas Technology, 36(2), 101-104. http://dx.chinadoi.cn/10.3969/j.issn.1000-9752.2014.02.021 (in Chinese)

Wang, C., Wang, F., Du, H., Zhang, X., 2014. Is China really ready for shale gas revolution-Reevaluating shale gas challenges. Environ. Sci. Policy 39, 49-55. http://doi.org/10.1016/j.envsci.2014.02.007

Wang, J.L., Feng, L.Y., 2016. A review of the impacts of shale gas development on water resources and GHG emissions. China Min. Mag. 4, 61-67. http://dx.chinadoi.cn/10.3969/j.issn.10044051.2016.04.013 (in Chinese)

Wang, J.L., Liu, M.M., Mclellan, B.C., Tang, X., Feng, L.Y., 2017. Environmental impacts of shale gas development in China: A hybrid life cycle analysis. Resour. Conserv. Recy. 120, 38-45. http://doi.org/10.1016/j.resconrec.2017.01.005

Xu, X., Zhang, B., 2015. Testing production of W204H2-2 reaching a higher level. 22th September 2015. http://www.dfblchina.com/c65054.jsp

Xia, L., Luo, D., Yuan, J., 2015. Exploring the future of shale gas in China from an economic perspective based on pilot areas in the Sichuan basin-A scenario analysis. J. Nat. Gas Sci. Eng. 22, 670-678. http://doi.org/10.1016/j.jngse.2015.01.016

Yu, M.J., Weinthal, E., Patiño-Echeverri, D., Deshusses, M.A., Zou, C.N., Ni, Y., Vengosh, A., 2016. Water availability for shale gas development in Sichuan basin, China. Environ. Sci. Technol. 6, 28372845. http://dx.doi.org/10.1021/acs.est.5b04669

Yin, C.B., Ye, D.S., Duan, G.B., Zhang, J.C., Deng, S.F., Wang, S.B., 2014. Research about and application of autonomous staged fracturing technique series for horizontal well stimulation of shale gas reservoirs in the Sichuan Basin. Nat. Gas Ind. 4, 67-71. http://dx.chinadoi.cn/10.3787/j.issn.10000976.2014.04.010 (in Chinese)

Yang, H.C., Mao, G.Y., Song, Q.C., Ji, Z.J., Liu, F.Z., 2014. Large scale fracturing technology of well Pengye HF-1 shale gas. J. Southwest Petrol. U. 5, 117-122. 
http://dx.chinadoi.cn/10.11885/j.issn.1674-5086.2012.08.30.04 (in Chinese)

Yang, J.X., Zou, S.L., Zhang, Y., Ni, F.J., Hu, Z.G., Ji, Y.L., 2015. Production Performance Analysis of Shale Gas Multi-Stage Fractured Horizontal Wells. J. Jianghan Petrol. U. Staff Work. 4, 19-22. http://dx.chinadoi.cn/10.3969/j.issn.1009-301X.2015.04.007 (in Chinese)

Yuan, J., Luo, D., Xia, L., Feng, L.Y., 2015. Policy recommendations to promote shale gas development in China based on a technical and economic evaluation. Energ. Policy 85, 194-206. https://doi.org/10.1016/j.enpol.2015.06.006

Zhao, J.Z., Fang, C.Q., Zhang, J., Wang, L., Zhang, X.X., 2011. Evaluation of China shale gas from the exploration and development of North America shale gas. Journal of Xi'an Shiyou University (Natural Science Edition), 26(2): 1-8. http://dx.chinadoi.cn/10.3969/j.issn.1673-064X.2011.02.001(in Chinese)

Zou, Y.F., Zheng, P., Liu, C., Yang, Y.F., Zhong, Y.S., Zhong, S.Q., 2013. Research on horizontal well fiber sand fracturing technology in Western Sichuan and its application. Nat. Gas Oil 5, 46-49. http://dx.chinadoi.cn/10.3969/j.issn.1006-5539.2013.05.012 (in Chinese)

Zhang, X., Sun, A.Y., Duncan, I.J., 2016. Shale gas wastewater management under uncertainty. J. Environ. Manage. 165, 188-198. https://doi.org/10.1016/j.jenvman.2015.09.038

Zhang, X.Q., Zhu, K.X., 2014. Application of KIMRAY pneumatic diaphragm valve in Fuling shale gas well gas-station. Jianghan Petrol. Sci. Technol. 3, 59-61. http://mall.cnki.net/magazine/Article/JHSK201403019.htm (in Chinese)

Zeng, F.H., Guo, J.C., Liu, H., Xiao, Y., 2013. Experience of efficient fracturing of shale gas in North America and enlightenment to China. J. Southwest Petrol. U. 6, 90-98. http://dx.chinadoi.cn/10.3863/j.issn.1674-5086.2013.06.012 (in Chinese) 